\title{
本態性高血圧自然発症ラットの血圧および血清脂質レベルに 及ぼす自己消化処理したシイタケの影響
}

\author{
渡辺敏郎 ${ }^{* * *}$ ，山田貴子 ${ }^{*}$, 石 知史 ${ }^{* *}$, Mazumder Tapan Kumar**, \\ 永井史郎 ${ }^{* *}$, 辻 啓介*
Effect of Autolyzed-Shiitake (Lentinus edodes) on Blood Pressure and Serum Fat Levels in Spontaneously Hypertensive Rats

\author{
Toshiro Watanabe $e^{* * \star}$, Takako Yamada*, Satoshi Ishi**, Tapan Kumar Mazumder**, \\ Shiro Nagai** and Keisuke Tsuji* \\ * School of Humanities for Enviromental Policy and Technology, Himeji Institute of Technology, \\ Shinzaike-Honcho, Himeji, Hyogo 670-0092, Japan \\ ** YAEGAKI Technology Development Laboratories, YAEGAKI Bio-industry, Inc., \\ Hayashida, Himeji, Hyogo 679-4298, Japan
}

The effect of shiitake (Lentinus edodes, LE) and autolyzed- (fermented-) shiitake (Autolyzed-LE) on blood pressure and serum fat levels of spontaneously hypertensive rats (SHR) were studied. Powdered LE or Autolyzed-LE was fed to SHR at the levels of $2 \%$ in a $1 \% \mathrm{NaCl}$ (control) diet for 21 days. The blood pressure was measured by tail cuff. The animals of the Autolyzed-LE group showed significantly lower blood pressure compared to the control or LE group. The serum levels of total cholesterol (TC), triglyceride and phospholipid of the groups fed with LE and Autolyzed-LE were lower than those of the control group, and atherogenic index [(TC-HDL-C)/HDL-C] improved significantly in 21 days. It was suggested that the serum TC decline is the action of eritadenine that is contained in the shiitake. An inhibitory activity of the angiotensin I-converting enzyme (ACE) was compared between of LE and Autolyzed-LE. The IC 50 of LE and Autolyzed-LE for ACE were 2500 and $490 \mu \mathrm{g} / \mathrm{ml}$, respectively. Autolyzed-LE showed higher inhibitory activity than LE against the ACE. These phenomena suggested that the hypotensive action of Autolyzed-LE was due to concomitant $\mathrm{ACE}$ inhibitory activities of peptides and $\gamma$-aminobutyric acid contained in higher amounts during the autolysis of LE.

(Received May. 7, 2002 ; Accepted Jul. 29, 2002)

シイタケ (Lentinus edodes) は, 東南アジアを中心に 広く分布し，わが国では春と秋に主に広葉樹の枯幹や倒 木などに発生する食用のキノコである. 栽培には原木栽 培之菌床栽培の 2 種類があり, 原木栽培はコナラやクヌ ギなどの原木に植菌し，原木中の養分のみで栽培する. 一方，菌床栽培はオガクズに栄養体を混ぜ，シイタケを 生育させる人工栽培法で質・量とす安定的に生産できる

\section{ことが特徽である.}

シイタケにはいくつかの生理機能が知られているが, 例えば血中コレステロール低下作用があり，これは水溶 性区分に溶出するエリタデニンの作用であることが報告

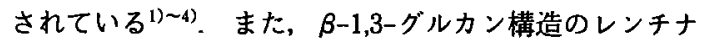

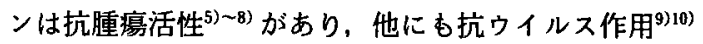
を示す成分む単離されている. シイタケはビタミンDの

* 姫路工業大学環境人間学部 (T670-0092 兵庫県姫路市新在家本町 1-1-12)

**ヤエガキ酸酔技研株式会社（干679-4298 兵庫県姫路市林田町六九谷 681）

$\S$ 連絡先 (Corresponding author), watnb-ts@yaegaki.co.jp 
前駆体であるエルゴステロールや食物繊維も豊富に含ん でいることから有用な食材であることがいえるい!.

わが国では高龄者人口が増加の一途にあり，一般に加 龄とともに血圧が高くなることから，高血圧に対処する 課題は重要であると考えられる。キノコには健康維持に 有用な生理機能成分を含むすのが多く，中でも霊 芝 $^{(2) 13)}$, 冬虫夏草 ${ }^{14)}$, マイタケ ${ }^{15) \sim 17)}$, アガリクス茸 ${ }^{(8) \sim 21)}$ では多数の研究結果が報告されている. また，わが国の 食用キノコの中で, 最む食されているシイタケす様々な 機能性を有することで知られている(1) 1122223). そこで, このシイタケを自己消化によりさまざまな有用成分の抽 出率を高めることで, シイタケの機能性向上を目的とし たキノコ粉末を作成した. 本研究では，この自己消化処 理したシイタケが本態性高血圧自然発症ラット（SHR） の血圧扝よび血清脂質レベルに対してどのような影響を 及ぼすかを検討した。

\section{実 験 方 法}

\section{1. 実験試料}

日本国内において栽培された乾燥シイタケ子実体の粉

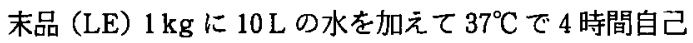
消化させた後, 殺菌, 凍結乾燥, 粉砕により $980 \mathrm{~g}$ の自己 消化シイタケ粉末品 (Autolyzed-LE) を得た. この LE および Autolyzed-LE の一般成分分析表を Table 1 に 示したが、 LEに比べて Autolyzed-LE は, 食物繊維や B-グルカン含量がやや减少し, 逆に遊離アミ，酸含量は 増加した，その他の成分には大きな違いはなかった。

Table 1 Component concentration in LE and Autolyzed-LE

\begin{tabular}{lrr}
\hline Contents $(\%)$ & LE* & $\begin{array}{c}\text { Autolyzed- } \\
\text { LE** }\end{array}$ \\
\hline Carbohydrate & 19.77 & 22.00 \\
Protein & 18.23 & 18.16 \\
Fat & 1.58 & 1.57 \\
Dietary fiber & 47.43 & 43.74 \\
B-Glucan & 27.22 & 21.90 \\
Free amino acid & 2.06 & 4.23 \\
GABA & 0.07 & 0.13 \\
Ash & 4.49 & 4.54 \\
Moisture & 8.50 & 9.99 \\
\hline
\end{tabular}

Values are means of 3 estimates.

* LE : Fruit body of Lentinus edodes

${ }^{* *}$ Autolyzed-LE : Autolyzed-Lentinus edodes

\section{2. 遊離アミノ酸の測定}

試料を 200〜 400 倍の水でけん濁した後, $0.45 \mu \mathrm{m}$ のメ ンブランフィルターDismic-13cp（Advantec 製) に通 し，オルトフタルアルデヒド（OPA）ポストカラム誘導 体化液体クロマトグラフ (OPA-HPLC) 法 (島津製 RF. 535, カラム Shim-pack Amino-Na $100 \mathrm{~mm} \times 6.0 \mathrm{~mm}$ ) にてアミ，酸含量を測定した. 各アミノ酸の検量線は $0.5 \mu \mathrm{M} \sim 25 \mu \mathrm{M}$ までの濃度範囲で作成した。

\section{3. エリタデンの確認}

エリタデニンは, 荒川らの方法 ${ }^{24)}$ に準じて薄層クロマ トグラフ（TLC）およびマトリックス支援イオン化-飛 行時間型質量分析計（MALDI-TOF-MS）によって確認 した. すなわち TLCプレート（シリカゲル 60 F254, 関 東化学) を $105^{\circ} \mathrm{C}$ で 30 分間活性化させた後, $\mathrm{n}$ ーブタ ノ一ル:酢酸 : 水=4:2:1の混合溶媒で展開させ, 紫外 線（UV-C， $254 \mathrm{~nm}$ ）の照射により，Rf 0.33 付近に得ら れる鮮明な赤紫色のスポットとして識別した.この部分 をかき取って水に溶解させ, マトリックスに $\alpha$-シアノー 4ーヒドロキシ桂皮酸を用いて MALDI-TOF-MSにより エリタデニンの分子量を確認した.

\section{4. 動物実験}

（1）実験動物の飼育方法および試料組成 実験動物は星野試験動物飼育所（埼玉県八潮市）加ら入 手した雄性 SHR を用いた．飼育及び保管に関しては総 理府告示第 6 号（昭和 55 年 3 月）の基準に沿っておこ なった，飼料の基本組成は Table 2 に示したように AIN 組成に基づいた，血圧を上昇させるために飼料中に食塩 を $1 \%$ 加え，LE および Autolyzed-LE は $2 \%$ 添加して サッカロースで $100 \%$ となるように調整した。 また，実 験飼料の給餌期間以外は，市販の固形飼料 CE-2（日本ク レア製) を与えた。，固形飼料で 7 日間飼育後，試験飼料 に切り替え 21 日間飼育した. 飲料水はイオン交換水を 用いて飼料とともに自由摄取とした．飼育室は，温度 23 $\pm 1^{\circ} \mathrm{C}$ ，照明は 12 時間おきに自動的に明（7：00〜19： 00）暗に切り替わるように調整し，個別ケージで飼育し た.

（2）血圧測定と血清脂質湘定方法

血圧は飼育初日および 7 日間ごと午前 $9: 00$ より各群 より 1 匹ずつ無作為に選び，無加温型非観血式血圧計 Model MK-2000 (室町機械製) を用いて， $23^{\circ} \mathrm{C}$ 以上の室 温で尾動脈圧の収縮期および拡張期血圧を無麻酔下の間 接（カフ）法により測定した，血液は血圧測定後，毎回 ただちに尾部より採血し，血清脂質（総コレステロール (TC), 高密度リポ蛋白質コレステロール（HDL-C）, ト 
リグリセリド (TG)、リン脂質 (PL)) は協和メデックス 製キット醉素法により定量した. TCから HDL-Cを差 し引き,超低比重リポ蛋白質コレステロール (VLDL-C) 十低比重少蛋白質コレステロール（LDL-C）とした. HDL-C と VLDL-C + LDL-C の比加ら動脈硬化指数 （AI）を算出した.

5. アンジオテンシンー | 変換酵素阻害実験

アンジオテンシンーI変換酵素 (ACE) 阻害実験は, 上 プリルヒスチジルロイシン（HHL）を基質に ACEによ り酵素反応させ，生成した馬尿酸を定量することにより 測定した ${ }^{25}$ ）すなわち ACE（Sigma 製，ウサギ肺由来, 5.5 units/mg-protein）を含む $125 \mathrm{mM}$ ホウ酸ナトリウ 厶繮衝液 $(\mathrm{pH} 8.3)$ を $50 \mu l$ と試料 $(0.5 \mathrm{M} \mathrm{NaCl}$ を含む上 記缓衝波にけん濁した LE およびAutolyzed-LE） $60 \mu \mathrm{l}$ を試験管に取り, $37^{\circ} \mathrm{C}$ で 3 分間予備加熱した後, $6.5 \mathrm{mM}$ の $\mathrm{HHL}$ 溶液を $300 \mu \mathrm{l}$ 添加し， 1 時間䤃素反応させた。 $1 \mathrm{M}$ の $\mathrm{HCl} 200 \mu l$ 加え反応を停止し，酢酸エチルを $0.8 \mathrm{~m} l$ 加え，遊離した馬尿酸を抽出した。抽出液 $0.5 \mathrm{~m} l$ をエバポレーターで蒸発乾固した後，それを蒸留水 0.5 $\mathrm{ml}$ に溶解して $228 \mathrm{~nm}$ で吸光度を測定し, ACE 活性阻 害濃度 $\left(\mathrm{IC}_{50}\right)$ を算出した.

\section{6. 統計処理}

各群とも平均值士標準偏差 (SD) で示し, 群間の有意 差検定には, 市販のソフトゥエア「StatView J5.0」を用 いて Tukey-Kramer の多重比較検定をおこない, $p<$ 0.05 で判定した.

Table 2 Composition of tested diets

\begin{tabular}{lccc}
\hline Constituents (\%) & Control & LE & $\begin{array}{c}\text { Autolyzed- } \\
\text { LE }\end{array}$ \\
\hline Casein & 22 & 22 & 22 \\
Lard & 10 & 10 & 10 \\
Mineral mixture* & 3.5 & 3.5 & 3.5 \\
Vitamin mixture* $^{*}$ & 1 & 1 & 1 \\
Choline bitartrate $^{*}$ & 0.2 & 0.2 & 0.2 \\
Sodium chloride & 1 & 1 & 1 \\
Cellulose** & 3 & 3 & 3 \\
LE & - & 2 & - \\
Autolyzed-LE & - & - & 2 \\
Saccharose & 59.3 & 57.3 & 57.3 \\
\hline
\end{tabular}

15 week old 18 male SHR divided into 3 groups.

* AIN-96 ${ }^{\mathrm{TM}}$ mixture

** PC-200 (Danisco Cultor Japan Ltd.)

\section{実 験 結 果}

\section{LE および Autolyzed-LE の遊離アミノ酸含量}

LE および Autolyzed-LEの遊離アミ，酸含量を調へ た結果を Fig. 1 に示した. Autolyzed-LE は，LEを自 己消化させたことから LE が有するプロテアーゼなどの 酵素反応により遊離アミノ酸含量が大きく増加した。な かでもバリン, ロイシン, イソロイシン, フェニルアラ 一ンが顕著に増加し，血圧降下に有効とされる GABA も自己消化により倍增した。

2. LE および Autolyzed-LE の投与における SHR の体重および摄食量の変化

15 週齢の SHR を 1 群 6 匹となるようにコントロール 群, LE 群および Autolyzed-LE 群の 3 群に分け試験し た. 実験終了時の体重はコントロール群では $343 \pm 14 \mathrm{~g}$, LE 投与群では $358 \pm 16 \mathrm{~g}$, Autolyzed-LE 投与群では 352 $\pm 13 \mathrm{~g}$ であった. このように, LE および Autolyzed-LE の投与において SHR の体重が著しく変化することは認 められなかった．また攝食量においても各群とも大きな

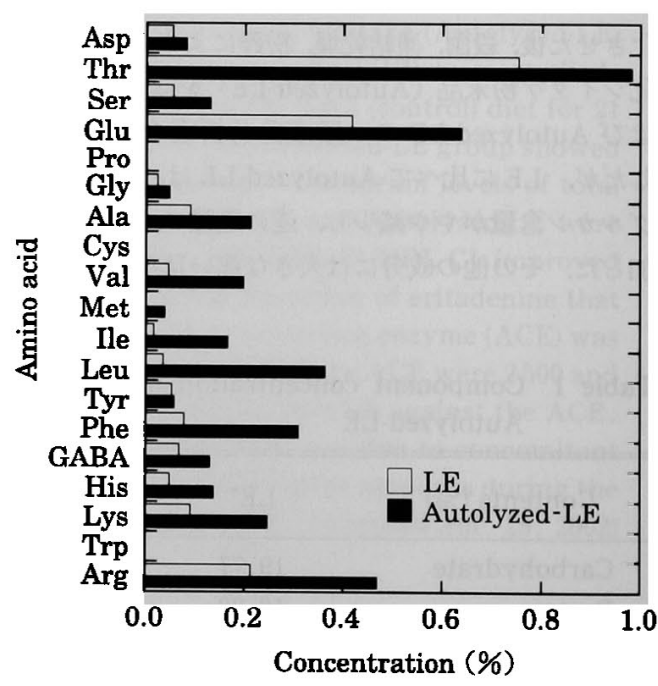

Fig. 1 Determination of free amino acids in LE and Autolyzed-LE by HPLC analysis

Fluorescence detection using OPA postcolumn reaction HPLC system conditions was as follows: column, Shim-pack Amino$\mathrm{Na} 100 \mathrm{~mm} \times 6.0 \mathrm{~mm}$; flow rate, $0.6 \mathrm{ml} / \mathrm{min}$; column temperature, $60^{\circ} \mathrm{C}$; detection, Ex 350 $\mathrm{nm}, \mathrm{Em} 450 \mathrm{~nm}$. Data are mean \pm SD from three determinations. 


\section{変化は認められなかった。}

\section{LE および Autolyzed-LE の投与における SHR} の血圧変動

LE および Autolyzed-LE を食鲯成分しして投与した SHR の 21 日間にわたる収縮期血圧および拡張期血圧の 経時変化を Fig. 2 に示した.コントロール群の収縮期血 圧值に対して, LE 投与群の血圧值はコントロール群と ほぼ同様の傾向が見られたが，Autolyzed-LE 投与群で は 7 日後からコントロール群抢よびLE投与群に対して 血圧値を有意に降下させた．また，その後の更なる血圧 降下は見られず，最終的にはコントロール群で 199 18 $\mathrm{mmHg}$, LE 投与群で $189 \pm 12 \mathrm{mmHg}$, Autolyzed-LE 投与群で $168 \pm 8 \mathrm{mmHg}$ となった。拡張期血圧も収縮期 血圧と同様に LE 投与群ではコントロール群と同様に血 圧値に有意な差は認められなかった。そして, Autolyzed-LE 投与群では 7 日後からコントロール群お よび LE 投与群に対して血圧值を有意に降下させた。

4. LE および Autolyzed-LE の投与における SHR

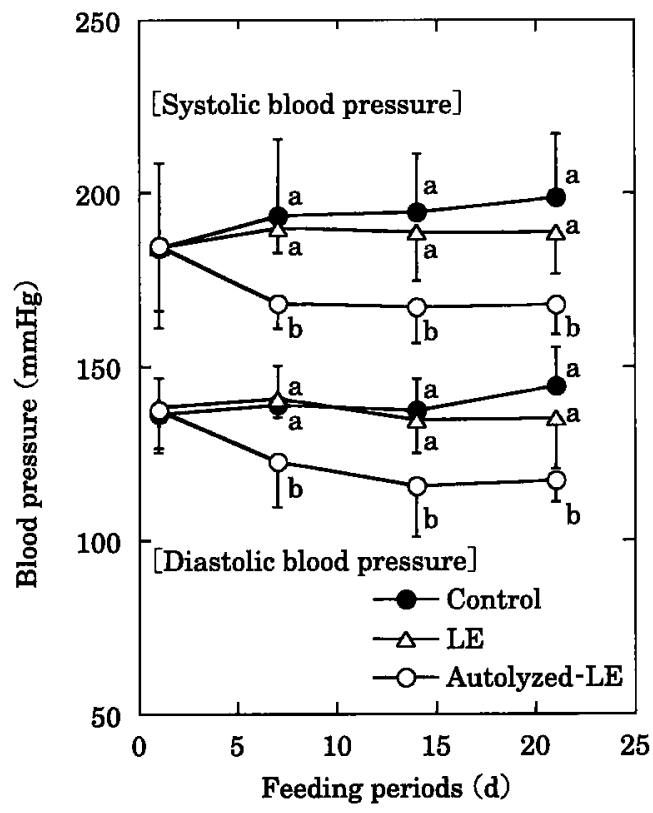

Fig. 2 Changes of systolic and diastolic blood pressure in SHR fed $1 \% \mathrm{NaCl}$ diets supplemented with LE or Autolyzed-LE

Vertical bars represent the mean $\pm S D$ for 6 male rats. Values in same period not followed by the same alphabetical letter are significantly different $(p<0.05)$.

\section{の血清脂質レベルの変化}

Table 3 にSHR の尾部からの採血による血清脂質レ ベルの変化について調べた結果を示した，試験を開始し て7日目でLEおよびAutolyzed-LE 投与群はコント ロール群に比べて TC, HDL-C, AI, TG, PL の值を有意に 低下させ, 試験終了の 21 日目まで同様の有意差を示し た.

5. LE および Autolyzed-LE 中に存在するエリタデ ニンの確認

TLCにより LE および Autolyzed-LE の熱水抽出液 を展開したところ主な成分が 2 種類得られた。これらの 成分を MALDI-TOF-MSにより分子量を調へ，構造解 析したところ Rf 0.33 に展開した成分はエリタデニン (分子量, 253) であり, Rf 0.68 に展開した成分はアデノ シン（分子量，267）であることがわかった（Fig. 3). ま た，TLCの結果より，エリタデニン执よびアデノシン含 量は LE, Autolyzed-LE ともにほぼ同程度であった。

\section{LE および Autolyzed-LE の ACE 活性阻害}

LE および Autolyzed-LEの ACE 活性阻害濃度を調 ベたところ, LEの $\mathrm{IC}_{50}$ 值は $2500 \mu \mathrm{g} / \mathrm{m} l$, AutolyzedLE の IC 50 值は $490 \mu \mathrm{g} / \mathrm{m} l$ であり, Autolyzed-LE は LE に比べて約 5 倍活性が高かった，そこで, AutolyzedLE中のタンパク・ペプチド含量を調べた. AutolyzedLEを水でけん濁して，その上清中の全アミ/酸と遊離 アミノ酸を測定し, 全アミノ酸から遊離アミノ酸を差し 引くことでタンパク・ペプチド含量とした，その結果， タンパク・ペプチド含量の割合は $54 \%$ を占めることが わかった。

\section{考察}

本研究においてシイタケを自己消化させることによっ て遊離アミノ酸の増加が確認できた。これはシイタケ中 のプロテアーゼが作用したためと思われた．またTable 1 に示したように, GABA についてもその濃度を増加さ せることができた，我々は，アガリクス苗が有している グルタミン酸脱炭酸酵素 (GAD) 活性によりアガリクス 茸に GABA を高濃度（2\% 以上）に蓄積できることを報 告しているが26), シイタケの GAD はアガリクス茸に比 ベてその活性が弱いためアガリクス茸ほど多量の GABA を蓄積できなかったことが考えられた，しかし ながら，血圧降下作用を有する GABA 含有食品素材は 発芽玄米や紅靝など数多くあるが，いずれあ GABA 含 有量は $0.02 \sim 0.05 \%$ であり, Autolyzed-LE 中の GABA 含有量のほうがそれらよりあ多いことが示された。 
Autolyzed-LE およびLEが SHR の血圧に対してよ゙ のような影響を与えるのか調べたところ、コントロール 群に対して Autolyzed-LE と LE 投与群は体重変化や摄 食量に大きな差は認められなかった。しかしながら， Autolyzed-LE 投与群は血圧值を有意に降下させた。 シ イタケの血圧降下作用は既に報告されているが27)，それ はシイタケ粉末を飼料中に $5 \%$ 添加しておう，本研究で はシイタケ粉末を $2 \%$ 添加した条件で実験をおこない， シイタケを自己消化させることの優位性を示した。これ は Autolyzed-LE に含まれるGABA やその他の成分が 血圧值の降下に作用していることが考えられた，LE お よび Autolyzed-LEにはシイタケ特有の核酸成分が含 まれている. TLCと MALDI-TOF-MS の結果からそれ らはエリタデニン28)とアデノシンであることが確認さ れた，アデノシンは血管拡張による血圧降下作用のある

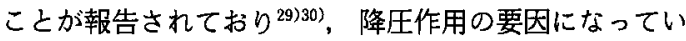

ることが考えられた．同時に ACE 阻害活性について調 ぶたところ，LEに比べて Autolyzed-LE は約 5 倍活性 が高かった．これは自己消化によりプロテアーゼが作用 することで，ペプチド成分が増加し， ACEの阻害活性が 向上したと考えられた。つまり，Autolyzed-LEの水溶 性区分の全アミノ酸から遊離アミノ酸を差し引いたとこ ろタンパク・ペプチド含量の割合は $54 \%$ と多く、これ により Autolyzed-LE 中に存在するペプチドなどの降 圧成分が血圧降下作用に深く関与していることが示唆さ れた. 以上のことから自己消化処理したシイ夕ケは GABA による降圧作用，シイタケに含まれる水溶性の 核酸成分，そして ACE 阻害活性成分などが協働的に関 与して, SHR の血圧を降下させたことが支持された。

LE および Autolyzed-LE が SHR の血清脂質レベル に対する影響を調べた結果，両群とも血清中の TC，特 に（VLDL+LDL）-Cと TG, PL の値を有意に低下さ

Table 3 Analytical results of serum lipid levels in SHR fed $1 \% \mathrm{NaCl}$ diets supplemented with LE or Autolyzed-LE

\begin{tabular}{lcccc}
\hline \hline & Day 1 & Day & Day 14 & Day 21 \\
\hline TC (mg/d $l$ ) & & & & \\
Control & $69.4 \pm 2.3$ & $94.1 \pm 3.5^{\mathrm{a}}$ & $90.0 \pm 3.4^{\mathrm{a}}$ & $106.4 \pm 6.7^{\mathrm{a}}$ \\
LE & $72.0 \pm 6.3$ & $62.4 \pm 9.9^{\mathrm{b}}$ & $62.4 \pm 8.2^{\mathrm{b}}$ & $68.9 \pm 7.3^{\mathrm{b}}$ \\
Autolyzed-LE & $69.9 \pm 4.9$ & $62.5 \pm 6.9^{\mathrm{b}}$ & $61.2 \pm 4.9^{\mathrm{b}}$ & $64.7 \pm 4.5^{\mathrm{b}}$ \\
HDL-C (mg/d $l)$ & & & & \\
Control & $59.1 \pm 8.0$ & $61.4 \pm 2.1^{\mathrm{a}}$ & $54.0 \pm 2.7^{\mathrm{a}}$ & $58.0 \pm 8.4^{\mathrm{a}}$ \\
LE & $61.8 \pm 5.5$ & $46.2 \pm 3.2^{\mathrm{b}}$ & $43.2 \pm 1.3^{\mathrm{b}}$ & $46.9 \pm 3.5^{\mathrm{b}}$ \\
Autolyzed-LE & $64.9 \pm 4.1$ & $48.7 \pm 3.0^{\mathrm{b}}$ & $45.1 \pm 2.2^{\mathrm{b}}$ & $46.1 \pm 3.5^{\mathrm{b}}$ \\
AI* & & & & \\
Control & $0.23 \pm 0.15$ & $0.61 \pm 0.07^{\mathrm{a}}$ & $0.66 \pm 0.11^{\mathrm{a}}$ & $0.86 \pm 0.20^{\mathrm{a}}$ \\
LE & $0.18 \pm 0.09$ & $0.33 \pm 0.15^{\mathrm{b}}$ & $0.43 \pm 0.19^{\mathrm{b}}$ & $0.47 \pm 0.13^{\mathrm{b}}$ \\
Autolyzed-LE & $0.14 \pm 0.04$ & $0.33 \pm 0.09^{\mathrm{b}}$ & $0.39 \pm 0.06^{\mathrm{b}}$ & $0.41 \pm 0.08^{\mathrm{b}}$ \\
TG (mg/d $l$ ) & & & & \\
Control & $87.0 \pm 18.0$ & $372.3 \pm 71.3^{\mathrm{a}}$ & $287.0 \pm 91.0^{\mathrm{a}}$ & $395.7 \pm 48.1^{\mathrm{a}}$ \\
LE & $85.4 \pm 19.0$ & $242.7 \pm 70.0^{\mathrm{b}}$ & $148.8 \pm 44.5^{\mathrm{b}}$ & $135.1 \pm 58.9^{\mathrm{b}}$ \\
Autolyzed-LE & $87.7 \pm 9.8$ & $197.9 \pm 52.0^{\mathrm{b}}$ & $168.8 \pm 13.7^{\mathrm{b}}$ & $107.1 \pm 10.1^{\mathrm{b}}$ \\
PL (mg/d $l$ ) & & & & \\
Control & $142.9 \pm 7.2$ & $205.0 \pm 13.7^{\mathrm{a}}$ & $202.9 \pm 11.9^{\mathrm{a}}$ & $213.3 \pm 17.6^{\mathrm{a}}$ \\
LE & $135.2 \pm 8.3$ & $151.9 \pm 24.7^{\mathrm{b}}$ & $128.1 \pm 13.7^{\mathrm{b}}$ & $139.6 \pm 10.6^{\mathrm{b}}$ \\
Autolyzed-LE & $141.6 \pm 8.9$ & $141.3 \pm 8.2^{\mathrm{b}}$ & $133.2 \pm 7.6^{\mathrm{b}}$ & $141.2 \pm 12.5^{\mathrm{b}}$ \\
\hline
\end{tabular}

* Atherogenic index : [(TC-HDL-C)/HDL-C] Data represent in mean $\pm \mathrm{SD}$ for 6 male rats .

a. b Means within the same horizontal column that do not share a common superscript letter were significantly different $(p<0.05)$. 
せた. シイタケ中の血清脂質レベルを低下させる成分と してエリタデニンが報告されている(1) 4). 本実験では, Fig. 3 に示したように LE および Autolyzed-LEともに エリタデニンの存在が確認され，TLCの結果からその 含量はほぼ同程度であった、これによりLEおよび Autolyzed-LE 投与群が SHR の血清脂質レベルを低下 させたのはエリタデニンの作用であることが考えられ た.

以上，本研究の結果加ら，Autolyzed-LE の捸取によ り SHR の血圧は降下し，それはシイタケを自己消化に より得られた複数の降圧成分が協働的に関与し，またエ リタデニンの作用で血清脂質レベルを低下させることが わかった.

\section{要 約}

自己消化処理したシイタケが本態性高血圧自然発症
ラット（SHR）の血圧に対してどのような影響を及ぼす かを検討した。シイタケを自己消化させることにより遊

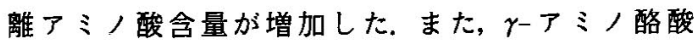
(GABA) についてす自己消化によりその含量加増加し た. 自己消化処理したシイタヶ (Autolyzed-LE) および 処理前のシイタケ (LE) を飼料中へ $2 \%$ 添加した場合で は, SHR に対して Autolyzed-LE 投与群がコントロー ル群に比べて有意に血压を降下させた。 しかし，LE群 はコントロール群に比べて血圧降下作用を示さなかっ た. Autolyzed-LEおよびLEにはエリタデニンやアデ ノシンが存在することが確認された，次に AutolyzedLEと LEについてアンジォテンシンーI 変換酵素 (ACE) 活性阻害効果を調べたところ, LEに比へて Autolyzed-LEの ACE 阻害活性は 5 倍高かった.これ により Autolyzed-LE の血圧降下作用はGABA，アデ ノシン, ACE 阻害活性成分などの相互作用により起

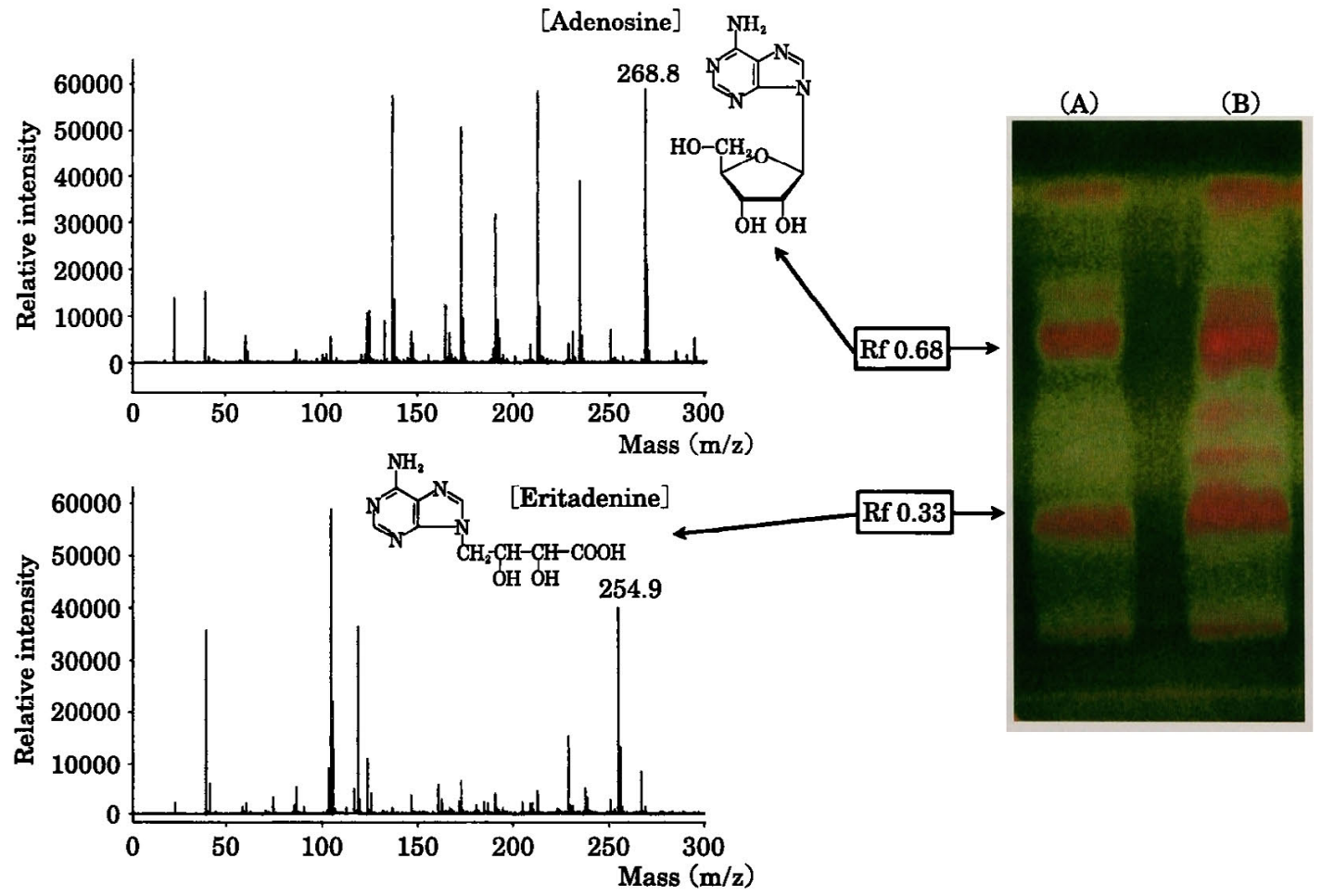

Fig. 3 Identification of eritadenine and adenosine by using TLC and MALDI-TOF-MS

(A) LE, (B) Autolyzed-LE. TLC conditions were as follows: plate, silica gel 60 F254; solvents, n-butanol : acetic acid : water $=4: 2: 1$; UV irradiation, UV-C $(254 \mathrm{~nm})$.

MALDI-TOF-MS conditions were as follows : matrix, $\alpha$-cyano-4-hydroxycinnamic acid ; mode, reflector ; ionization, positive. 
こっていることが考えられた. Autolyzed-LEおよび LEを食䬣成分として SHR に与えた結果, 血清総コレ ステロール (TC), 特に (VLDL+LDL) - C,トリグリ セリド（TG），動脈硬化指数，リン脂質 (PL) の值が有 意に低下した。これはシイタケに含まれるエリタデニン の作用であることが考えられた。

\section{文献}

1) Takashima, K., Sato, C., Sasaki, Y., Morita, T. and Takeyama, S., Effect of eritadenine on cholesterol metabolism in the rat. Biochem. Pharmacol., 23, 433-438 (1974).

2) Okumura, K., Matsumoto, K., Fukamizu, M., Yasuo, H., Taguchi, Y., Sugihara, Y., Inoue, I., Seto, M., Sato, Y., Takamura, N., Kanno, T., Kawazu, M., Mizoguchi, T., Saito, S., Takashima, K. and Takeyama, S., Synthesis and hypocholesterolemic activities of eritadenine derivatives. J. Med. Chem., 17, 846-855 (1974).

3）徳田節子, 鈴木 紳, 金田尚志, 食用きのこ類の 白ネズミコレステロール代謝に及ぼす影響（第 10 報) シイタケの血墏コレステロール低下機構 (IV) C14-エリタデニンの白ネズミ体内でのゆくえ, 栄 養と食糧, 29，95-101（1976）。

4）伊東牧子，川田澄子，山本信子，遠藤仁子，萩原 美恵子，原見彩子，大村京生，ラットの血獎怙よ び肝脂質におよばすエリタデニン投与の影響, 栄 養と食糧, 34, 65-69（1981）.

5) Maeda, Y.Y., Chihara, G. and Ishimura, K., Unique increase of serum proteins and action of antitumour polysaccharides. Nature, 252, 250-252 (1974).

6) Sasaki, T., Takasuka, N., Chihara, G. and Maeda, Y.Y., Antitumor activity of degraded products of lentinan : Its correlation with molecular weight. Gann, 67, 191-195 (1976).

7) 宮崎利夫, 真菌多糖類上免疫活性. 化学上生物, 17, 749-752 (1979).

8）林 良輔，落合武徳，渡辺一男，竜 崇正，西島 浩, 浅野武秀, 大塚雅昭, 坂本 蓄, 清水 謙, 古川隆男, 渡辺義二, 鈴木孝雄, 菊池俊之, 佐藤 博, 中村雅一, 持続動注による免疫化学療法が著 効を示した末期胃がんの一例. がんの臨床，26, 933-936 (1980).

9）都丸敬一，宇田川 晃，担子菌類子実体抽出液の 抗菌物辛イルス性. 植物防疫, 29, 17-19 (1975).

10）竹原 学, 杭田 要, 森 䙾一, シイタケウイル ス様粒子の抗ウイルス作用. 医学と生物学, 98, 273-276 (1979).

11) Kurasawa, S., Hayashi, J. and Sugahara, T.,
Stusies on dietary fiber of mushrooms and edible wild plants. Nutr. Rep. Int., 26, 167-173 (1982).

12）南雲英樹, 荻田善一，岡田知佐子，松下 功，松 野 明, 辻 陽雄, 霊芝成分の免度機能調節作用 に及ぼす影響について，和漢医薬学会誌，7，282283 (1990).

13）伊藤 均, 桐ヶ谷紀昌, 霊芝由来・抗腫瘍性多糖 体の細胞内皮系機能賦活作用. 医学々生物学, 127, 345-348 (1993).

14) Kuo, Y.C., Tsai, W.J., Wang, J.Y., Chang, S.C., Lin, C.Y. and Shiao, M.S., Regulation of bronchoalveolar lavage fluids cell function by the immunomodulatory agents from Cordyceps sinensis. Life Sci., 68, 1067-1082 (2001).

15) Adachi, K., Nanba, H. and Kuroda, H., Potentiation of host-mediated antitumor activity in mice by b-glucan obtained from Grifola frondosa (maitake). Chem. Pharm. Bull., 35, 262-270 (1987).

16）河岸洋和, キノコ由来の細胞機能調節物質, 農化. 68, 1671-1677 (1994).

17) Kurushima, H., Kodama, N. and Nanba, H. Activities of polysaccharides obtained from Grifola frondosa on insulin-dependent diabetes mellitus induced by streptozotocin in mice. Mycoscience, 41, 473-480 (2000).

18) Mizuno, M., Morimoto, M., Minato, K. and Tsuchida, H., Polysaccharides from Agaricus blazei stimulate lymphocyte T-cell subsets in mice. Biosci. Biotechnol. Biochem., 62, 434-437 (1998).

19) Mizuno, M., Minato, K., Ito, H., Kawade, M., Terai, H. and Tsuchida, H., Anti-tumor polysaccharide from the mycelium of liquidcultured Agaricus blazei Mill. Biochem. Mol. Biol. Int., 47, 707-714 (1999).

20）菊川忠裕，江口文陽，安部千之，吉本博明，桧垣 宮都，新規抗炎症物質 : 2 系の間接炎モレルマウ スに対する Agaricus blazei Murri (CJ-01) の影 響. 炎症, 19, 261-267 (1999).

21）渡辺敏郎，山田貴子，田中仁子，姜 聖花， Mazumder,T.K., 永井史郎, 辻 啓介，高血圧自 然発症ラットにおける $r$-アミノ酪酸蓄積アガリ クス茸の血圧降下作用. 食科工，49，166-173 (2002).

22）杉山公男，赤地利幸，村松敬一郎，シイタケ摂取 によるメチル化反応の抑制と血掣コレステロール 低下作用との関係. 必須アミノ酸研究，139，1-5 (1994). 
23) Lelik, L., Vitanyi, G., Lefler, J., Hegoczky, J., Nagy-Gasztonyi, M. and Vereczkey, G., Production of the mycelium of shiitake (Lentinus edodes) mushroom and investigation of its bioactive compounds. Acta Aliment., 26, 271-277 (1997).

24）荒川信彦, 向山晴美, 中井 恵, 中島和男, 田辺 修、稲垣長典，エノキタケ中の血洯コレステロー ル低下因子の分画. 栄養上食糧, 30, 35-38 (1977).

25) Cushman, D.W. and Cheung, H.S., Spectrophotometric assay and properities of the angiotensin-converting enzyme of rabbit lung. Biochem. Pharmacol., 20, 1637-1648 (1971).

26）姜 聖花, 渡辺敏郎, Mazumder T.K, 永井史郎, アガリクス自己消化による GABA 高含有素材の 開発. バイオインダストリー，19，25-31（2002）.

27) Kabir, Y., Yamaguchi, M. and Kimura, S., Effect of shiitake (Lentinus edodes) and maitake (Grifola frondosa) mushroom on blood pressure and plasma lipids of spontaneously hypertensive rats. J. Nutr. Sci. Vitaminol., 33, 341-346 (1987).

28) Vitanyi, G., Lelik, L., Bihatsi, K.E., Lefler, J., Nagy, G.M. and Vereczkey, G., Determination of eritadenine in extracts from shiitake mushroom by gas chromatography/mass spectrometry. Rapid commun. Mass spectrum., 12, 120-122 (1998).

29) Seemann, W.R., Mathias, K., Roeren, T.H., Urban, Y.B. and Kopp, K.H., Adenosine and diltiazem. A new therapeutic concept in the treatment of intestinal ischemia. Invest. Radiol., 20, 166-170 (1985).

30) Phillis, J.W. and Delong, R.E., The role of adenosine in cerebral vascular regulation during reductions in perfusion pressure. J. Pharm. Pharmacol., 38, 460-462 (1986).

(平成 14 年 5 月 7 日受付, 平成 14 年 7 月 29 日受理) 